\title{
STUDIES ON FLORAL BIOLOGY OF IxoRa agaSTHYAMALAYANa SIVADASAN \& MOHANAN - A RARE SOUTHERN WESTERN GHATS ENDEMIC
}

\author{
A.K. Sreekala, G. Rajkumar and A.G. Pandurangan ${ }^{1}$ \\ Tropical Botanic Garden and Research Institute, Palode, Thiruvananthapuram, Kerala 695562, India. \\ ${ }^{1}$ Corresponding author
}

\begin{abstract}
Ixora agasthyamalayana is a rare and endemic taxon of southern Western Ghats of Kerala. It flowers throughout the year under the climatic conditions of Agasthyamala and the peak during January. The floral biology of this plant was studied. Anthesis occurred between 0600 and $1300 \mathrm{hr}$ with its peak at $0700 \mathrm{hr}$. Anther dehiscence was observed between 0700 and $1300 \mathrm{hr}$ with a peak at $1000 \mathrm{hr}$. The maximum receptivity of stigma was found on the day of anthesis. Pollen grains were round, light pink in colour and $32.24 \mu \mathrm{m}$ in diameter.
\end{abstract}

\section{Keywords}

Anthesis, floral biology, Ixora agasthyamalayana, pollen grains, stigma receptivity, Western Ghats

\section{Introduction}

Ixora agasthyamalayana, a rare and endemic plant belonging to the family Rubiaceae is found in Agasthyamala Hills of southern Western Ghats. It is a shrub, growing in deep evergreen forests and is so far known only from the type locality. Flowering and fruiting are observed almost throughout the year (Sivadasan \& Mohanan, 1991). Flowers are pink, sessile or shortly pedicelled in pedunculate corymbs; stamens four, alternating with corolla lobes at throat; style slender, $1.5 \mathrm{~cm}$ long; ovary 2-celled, ovule one in each, placentation axile. In order to understand the narrow distribution and breeding behaviour of the species, a study on floral biology was undertaken. The knowledge of floral biology is a prerequisite in estimating the overall reproductive potentiality of a species which in turn, controls adaptive changes in the organisms (Simmonds, 1962).

\section{Materials and Methods}

The study was carried out on Ixora agasthyamalayana from Agasthyamala Hill ranges between November 2000 and February 2002. Ten healthy plants were selected in the community and observations were made on day-to-day basis on flowering season, flowering habit, flower development and anthesis. Peak flowering time was noted when maximum number of flowers opened. Fifty flower buds were selected and observation was made between 0500 to $1800 \mathrm{hr}$ to study the time of anthesis and anther dehiscence. Pollen ovule ratio was worked out as per the method suggested by Cruden (1977). Pollen fertility was assessed by using $2 \%$ acetocarmine and glycerine (1:1) staining technique. To study pollen germination in vitro, pollen grains collected from fresh flowers were incubated for eight hours in a drop of Brewbaker's medium containing 1\% sucrose. Pollen grains which had produced pollen tubes longer than the diameter of the pollen grains were counted as viable. Stigma receptivity was studied visually with the help of a hand lens and by hand pollination method. For the study of pollen germination on stigma ( in vivo), the flowers were labelled at the time of anthesis. The pistils were collected from the labelled flowers at different time intervals after anthesis. These pistils were boiled with lactic acid, stained with $10 \%$ cotton blue for 10 minutes, mounted on clean slides and examined microscopically.

\section{Results and Discussion \\ Floweringhabit}

Under the climatic conditions of Agasthyamala, Ixora agasthyamalayana starts flowering in the month of November, continuing throughout the year, and reaches a peak during January. The flower buds take 4-5 days from initiation to full bloom.

\section{Time of anthesis and anther dehiscence}

Anthesis commenced between 0600 and $1300 \mathrm{hr}$. About $84 \%$ of anthesis occurred between 0700 and $1000 \mathrm{hr}$ and maximum of $36 \%$ was recorded during the first hour of anthesis. There was no anthesis recorded between 1400 and $1700 \mathrm{hr}$. Anther dehiscence was observed after one hour of opening of flowers and maximum of $34 \%$ was noticed after four hours. The anther dehisce longitudinally and expose pollen grains (Table 1). The present observations concur with the study of Sarma et al., (1997) in Ocimum canum, where anthesis commenced at $0800 \mathrm{hr}$, reached its peak at $1100 \mathrm{hr}$ and declined by $1300 \mathrm{hr}$. The

Received 29 July 2002;

Revised received 24 January 2003;

Finally accepted 1 February 2003 
Table 1. Details of anthesis and anther dehiscence in Ixora agasthyamalayana

\begin{tabular}{lcccc}
\hline $\begin{array}{l}\text { Time } \\
\text { (Hrs) }\end{array}$ & $\begin{array}{l}\text { No. of Fls. } \\
\text { opened }\end{array}$ & $\begin{array}{l}\text { \% of Fls. } \\
\text { opened }\end{array}$ & $\begin{array}{l}\text { No. of Fls. } \\
\text { with anther } \\
\text { dehisced }\end{array}$ & $\begin{array}{l}\text { \% of Fls. } \\
\text { with anther } \\
\text { dehisced }\end{array}$ \\
\hline $0500-0600$ & 0 & 0 & 0 & 0 \\
$0600-0700$ & 8 & 16 & 0 & 0 \\
$0700-0800$ & 18 & 36 & 5 & 10 \\
$0800-0900$ & 10 & 20 & 7 & 14 \\
$0900-1000$ & 6 & 12 & 10 & 20 \\
$1000-1100$ & 3 & 6 & 17 & 34 \\
$1100-1200$ & 3 & 6 & 9 & 18 \\
$1200-1300$ & 2 & 4 & 2 & 4 \\
$1300-1400$ & 0 & 0 & 0 & 0 \\
$1400-1500$ & 0 & 0 & 0 & 0 \\
$1500-1600$ & 0 & 0 & 0 & 0 \\
$1600-1700$ & 0 & 0 & 0 & 0 \\
$1700-1800$ & 0 & 0 & 0 & 0 \\
\hline
\end{tabular}

dehiscence of anthers also took place between 0700 and $1300 \mathrm{hr}$ with a peak at $1000 \mathrm{hr}$.

\section{Pollen-ovule ratio}

The floral analysis indicates that each flower has four anthers and two ovules. A single anther contained 1200 pollen grains and thus a flower had around 4800 pollen. Hence P-O ratio was worked out as 2400 pollens per ovule (2400:1) which again confirms the pollination by zoophily (Cruden, 1977).

\section{Pollen germination}

Pollen grains are round and $32.24 \mu \mathrm{m}$ in diameter. The acetocarmine staining technique reveals that $88 \%$ of pollen grains are fertile. The maximum in vitro pollen germination of $72 \%$ was recorded in Brewbaker's medium containing 1\% sucrose and attained an average tube length of $340 \mu \mathrm{m}$.

Table 2. In vivo pollen germination before and after anthesis in Ixora agasthyamalayana

\begin{tabular}{lcc}
\hline Time & $\begin{array}{c}\text { \% of pollen } \\
\text { germination }\end{array}$ & $\begin{array}{c}\text { Pollen tube length } \\
(\mu \mathrm{m})\end{array}$ \\
\hline 6 hrs. before anthesis & 0 & 0 \\
At the time of anthesis & 38 & 180 \\
6 hrs. after anthesis & 58 & 310 \\
12 hrs. after anthesis & 52 & 280 \\
18 hrs. after anthesis & 46 & 260 \\
24 hrs. after anthesis & 38 & 222 \\
30 hrs. after anthesis & 32 & 160 \\
36 hrs. after anthesis & 28 & 146 \\
42 hrs. after anthesis & 14 & 110 \\
48 hrs. after anthesis & 8 & 60 \\
\hline
\end{tabular}

Table 3. Stigma receptivity and fruit set in Ixora agasthyamalayana

\begin{tabular}{lccc}
\hline Period & $\begin{array}{l}\text { No. of flowers } \\
\text { pollinated }\end{array}$ & $\begin{array}{l}\text { No. of } \\
\text { fruit set }\end{array}$ & $\begin{array}{l}\text { \% of fruit } \\
\text { set }\end{array}$ \\
\hline One day prior to anthesis & 50 & 0 & 0 \\
On the day of anthesis & 50 & 15 & 30 \\
One day after anthesis & 50 & 5 & 10 \\
Two days after anthesis & 50 & 0 & 0 \\
\hline
\end{tabular}

\section{Stigma receptivity}

The stigmas remained receptive at the time of flower opening and hence it is protogynous in nature. To confirm the receptivity of stigma, hand pollinated flowers were observed periodically for seed setting. The visual observations indicated that the stigma was wet and shiny on the day of anthesis, retained its status for 48 hours, after which it turned black. This observation was further supported by in vivo pollen germination tests. The results indicated that the maximum stigma receptivity was recorded on the day of anthesis and it had lasted for 48 hours giving different percentage of pollen germination on stigma (Table 2). Highest percentage of pollen germination (58\%) was recorded after six hours of anthesis which resulted in 30\% fruit set. On the contrary, the percentage of pollen germination declined considerably when pollinated after 24 hoursof anthesis which resulted in $10 \%$ fruit setting and thereafter no fruit set was observed (Table 3). The study agrees the observation of Baruah and Saha (1999) on Bacopa monnieri, where maximum stigma receptivity was observed on the day of anthesis with $26 \%$ fruit set, followed by the next day with $4 \%$ and thereafter no fruit setting was observed.

Receptivity of the stigma is a critical factor for the successful completion of post pollination events. It is usually maximal soon after anthesis and also it varies from species to species depending upon temperature and humidity (Shivanna \& Johri, 1989). The present investigation has shown that the stigma was maximally receptive on the day of anthesis which had resulted in moderate fruit setting in natural conditions.

\section{References}

Baruah, B.C. and B.N. Saha (1999). Study of floral biology of Bacopa monnieri. Journal of Economic and Taxonomic Botany 23: 705-708.

Cruden, R.W. (1977). Pollen- ovule ratios: A conservative indicator of breeding systems in flowering plants. Evolution 31: 32-46.

Sarma, P.C., S.C. Nath, K.K. Sarma and R.S. Singh (1997). Studies on Blossom biology of Ocimum canum. Indian Perfumer 41(2): 37-40.

Shivanna, K.R. and B.M. Johri (1989). The Angiosperm Pollen Structure and Function. Wiley Eastern Limited, New Delhi.

Simmonds, N.W. (1962). Variability, its use and conservation. Botanical Review 37: 422-465.

Sivadasan, M. and N. Mohanan (1991). Ixora agasthyamalayana, a new species of Rubiaceae from India. Botanical Bulletin of Academia Sinica. 32: 313-316. 